\title{
SOLAR WATER DISTILLER WITH SEPARATED CONDENSER OR THERMOSYPHON FOR REMOTE AND ARID AREAS
}

\author{
Mostafa A. Abd El-Baky \\ Mechanical Power Engineering Department, Faculty of Engineering, Minoufiya \\ University, Shebin El-Kom, Egypt.
}

\begin{abstract}
Two modifications of solar water distiller using cement and aluminum absorber are presented experimentally. The first modification using separated condenser to purge the water vapor from the cement absorber distiller to increase the condensation. The second modification using plate thermosyphon charged with acetone installed in the bottom of the water basin in aluminum absorber distiller to increase the input energy to distiller, thus increasing the water vaporization and condensation. The optimum tilted angle of glazing surface was obtained theoretically between $10 \sim 20^{\circ}$ at latitude angle of $30^{\circ}$. The daily productivity of cement absorber distiller was obtained of $2.08 \mathrm{~L} /\left(\mathrm{m}^{2}\right.$.day) and increased with percentage of $18.7 \%$ using separated condenser. For aluminum absorber distiller the average daily productivity was attained to $2.96 \mathrm{~L} /\left(\mathrm{m}^{2}\right.$.day) and increased to $3.49 \mathrm{~L} /\left(\mathrm{m}^{2}\right.$.day) using plate thermosyphon. The overall efficiency was increased from $50 \%$ to more than $65 \%$.

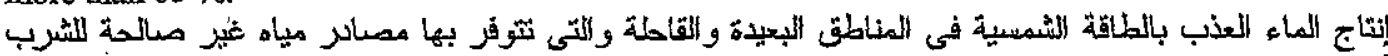

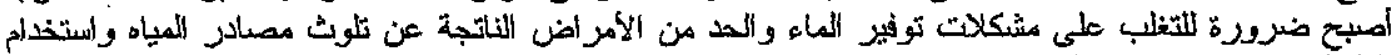

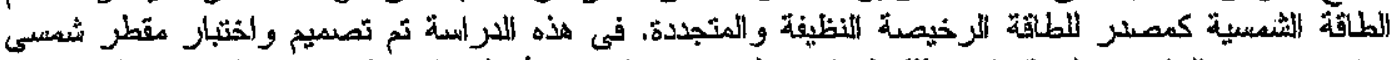

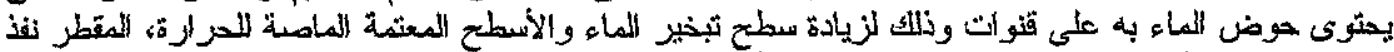

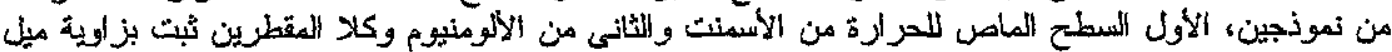

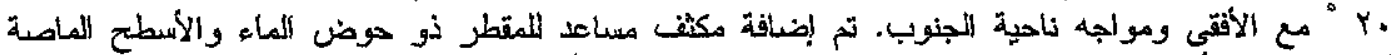

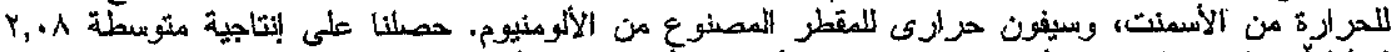

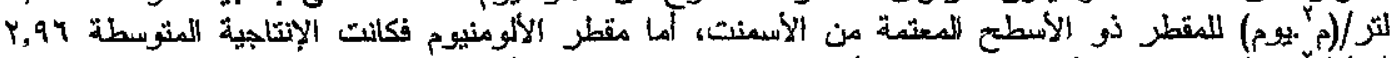

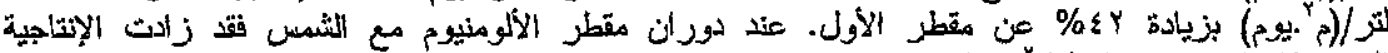

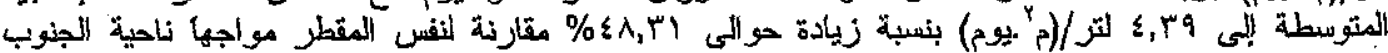

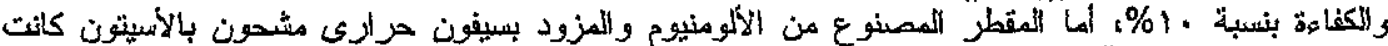

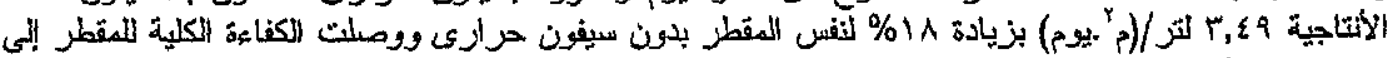
ما دون To \% \% \%
\end{abstract}

Keywords: Solar distiller, heat recovery, plate thermosyphon, distiller productivity.

\section{INTRODUCTION}

Fresh water is the saurce of life and corner stone of developing the modern civilization. Most of the human activities are intensively depending on the water resources such as underground water, rains, lakes and rivers for water requirements. However, rapid industrial growth and the population explosion allover the world have resulted in a large escalation of demand for fresh water. Add to this, the problems of pollution of rivers and lakes by industrial wastes and large amounts of sewage discharged [1]. While water covers about three-quarters of the earth' surface, only $3 \%$ is fresh water and not all of this limited quantity is suitable for drinking. Thus, water treatment is usually needed, and desalination is widely used for providing fresh water from brackish or seawater. Also, to supply the needed amount of potable water is already a problem in remote and arid areas which have a limited supply of conventional energy, but with a great potential for solar energy.
Solar distiller based on renewable, safe, free and clean energy is promising for a cost effective solution.

The producing of fresh water by solar distiller has been presented in many studies [2-4]. Several types of solar distillers are available, the simplest of which is the single-basin type, but the yield of this distiller is in the range of $2-4 \mathrm{~L} /$ day per $\mathrm{m}^{2}$ of distiller area. This distiller has the advantage of low installation cost and disadvantages of low efficiency, salt accumulation, and a short lifetime [5-7]. Many generations of solar systems and distiller have been developed but a very small number were put into practice because of low efficiency and small amount of fresh water. A new approaches of solar desalination for small and medium size used to enhance performance of solar desalination system was presented [8]. The productivity of $25 \mathrm{~L} /$ day per $\mathrm{m}^{2}$ was reached using such a system of heat recovery. Also, the solar distiller productivity was increased 
using a flat plate solar collector [9], and the maximum increase in the yield was up to $33 \%$ when the water is preheated in the collector.

There are recent works that investigated similar solar distillation systems with a heat-pipe solar collector [10-12]. They predicted the optimum angle of the solar collector theoretically and performed parametric investigation of design and operation conditions. The distiller is predicted to produce 21.8 $\mathrm{L} /$ day per $\mathrm{m}^{2}$ distilled water, and the productivity in this case is greater than that of a distiller coupled with bulky basin type. Performance analysis of a solar distiller coupled to a separated condenser was presented $[13,14]$. The separated condenser was used to purge the water vapor to be condensed. The efficiency of the distiller thereby was increased from $48 \%$ to more than $70 \%$, and the proposed solar distiller worked perfectly with daily yield of $7 \mathrm{~L} /$ day per $\mathrm{m}^{2}$.

The objective of the present study is to investigate the productivity of solar water distiller of cement and aluminum absorber. Two modifications of auxiliary condenser and plate thermosyphon to increase the distiller productivity were conducted. The effect of glazing surface tilted angle and orientation to south or opposite sun on the incident solar energy were taken into account. Comparison between aluminum absorber productivity and efficiency without and with thermosyphon orientated to south were also performed.

\section{MATHEMATICAL APPROACH OF SOLAR RADIATION}

The performance of solar distiller is related to the surface azimuth angle or orientation, $\psi$, and surface tilt angle, $\Sigma$. To clarify the optimum tilt angle of solar collector at certain site, the ASHARE model [15] is used to estimate the normal direct solar radiation intensity, $I_{N D}$, the normal component to the tilted surface, $I_{N S}$ and solar incident angle, $\theta$, which lies between the normal direct solar radiation and the normal component to the tilted surface as shown in Fig. 1.

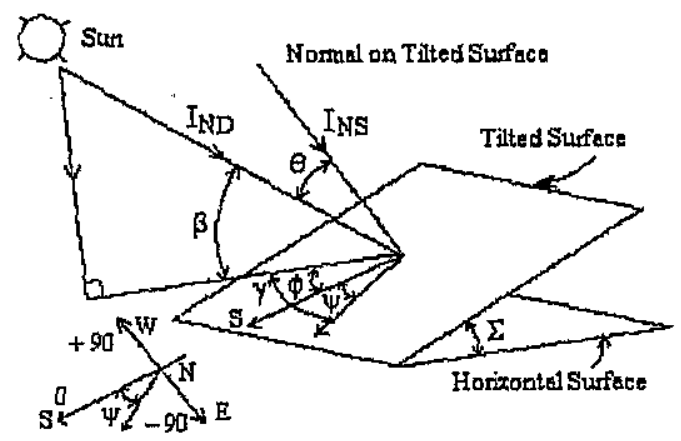

Fig. 1 Direct solar radiation and incident normal component on tilted surface

$$
\begin{aligned}
& I_{N D}=A e^{-B / \sin \beta} \\
& I_{N S}=I_{N D} \cos \theta \\
& \theta=\cos ^{-1}(\sin \beta \cos \Sigma+\cos \beta \cos \gamma \sin \Sigma)
\end{aligned}
$$

Where the solar plane azimuth angle, $\gamma=\phi-\psi$, and $\phi$ is the solar azimuth angle. Thus, the global solar radiation, $I_{G}$, on the horizontal surface, $\Sigma=0$ is calculated as follows,

$$
I_{G}=I_{N D}(\sin \beta+C)
$$

Total solar radiation incident on the tilted surface with angle, $\Sigma$, is given by the following equation:

$I_{T S}=I_{N S}+I_{D S}+I_{R g}$

The diffused radiation, $I_{D s}$ and the radiation reflection from the earth surface, $I_{R g}$, are defined as:

$I_{D s}=C I_{N D} F_{S S}$

$I_{R g}=\rho_{g} F_{S g} I_{N D}(\sin \beta+C)$

Where,

$F_{S S}=(1+\cos \Sigma) / 2$

$F_{S g}=1-F_{S S}=(1-\cos \Sigma) / 2$

By substituting of Eqs. $(2,6-9)$ into Eq. (5), yields

$I_{T S}=I_{N D}\left[\cos \theta+C F_{S S}+\rho_{g} F_{S g}(\sin \beta+C)\right]$

The solar radiation outside the atmosphere $A$, the constants, $B, C$, and formulas of solar angles are available in Appendix B as given in reference [15]. A computer program has been developed using Eqs. (1 to10) with the formulas of solar angles to estimate the normal direct solar radiation, the total solar radiation incident on a tilted surface at different tilt angles, $\Sigma$, and surface azimuth angles, $\psi$. To validate the accuracy of the program, the global solar radiation was measured at Menoufiya University, Shebin El-kom, Egypt with EPPLEY Radiometer (PSP) and the data were taken every 15 minutes as shown in Fig 2 and 3. It can be seen that there is a regular variation from sunrise to sunset and peak radiation is recorded at noon. The estimated values of global radiation are closed to the measured data. It may be noticed that the agreement in general is fairly good and the deviation of the estimated to the measured global radiation, $I_{G}^{+}$can be expressed by the following relation:

$I_{G}^{+}=\left(I_{G_{E s t i m o t e d}}-I_{G_{\text {Measuret }}}\right) / I_{G_{\text {Measured }}}$ 


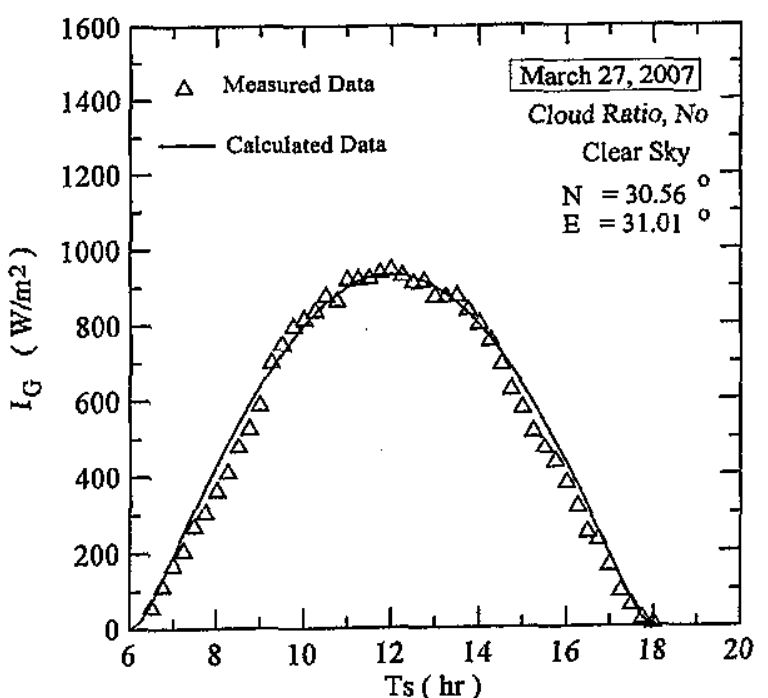

Fig. 2 Global solar radiation on Shebin El-kom

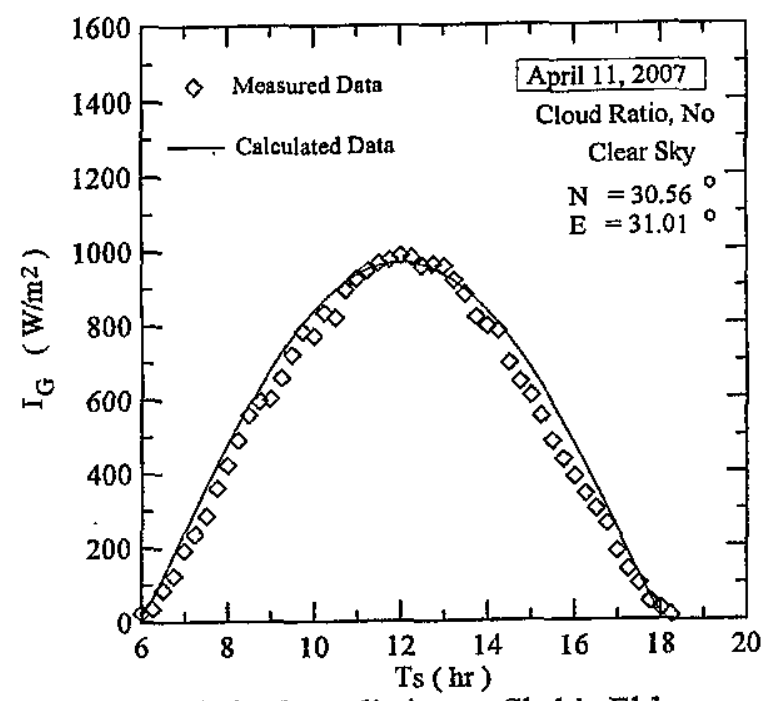

Fig. 3 Global solar radiation on Shebin El-kom.

The standard deviation or root mean square deviation was employed to estimate the relative error of $I_{G}^{+}$as follows:

$S D=\sqrt{\sum_{i=1}^{i=n}\left(I_{G, i}^{+}\right)^{2} / n}$

The percentage deviation of estimated global solar radiation relative to measured one was illustrated in Fig. 4. It is observed that the agreement is satisfactory around noon from $9 \sim 15$ O'clock. The percentage deviation from sunrise to 9 O'clock is positive in the range of $0 \sim 17 \%$, because the estimated was higher than measured global radiation due to the effect of relative humidity in the morning. But the percentage deviation from 15 o'clock to sunset was negative of $0 \sim-8 \%$, because the measured is higher than estimated due to the increase of diffuse radiation. The root mean square was $5.02 \sim$
$7.85 \%$. Its low value clearly proves that the proposed mathematical approach can be used for estimating the global solar radiation on horizontal and tilted surface at any location with high confidence.

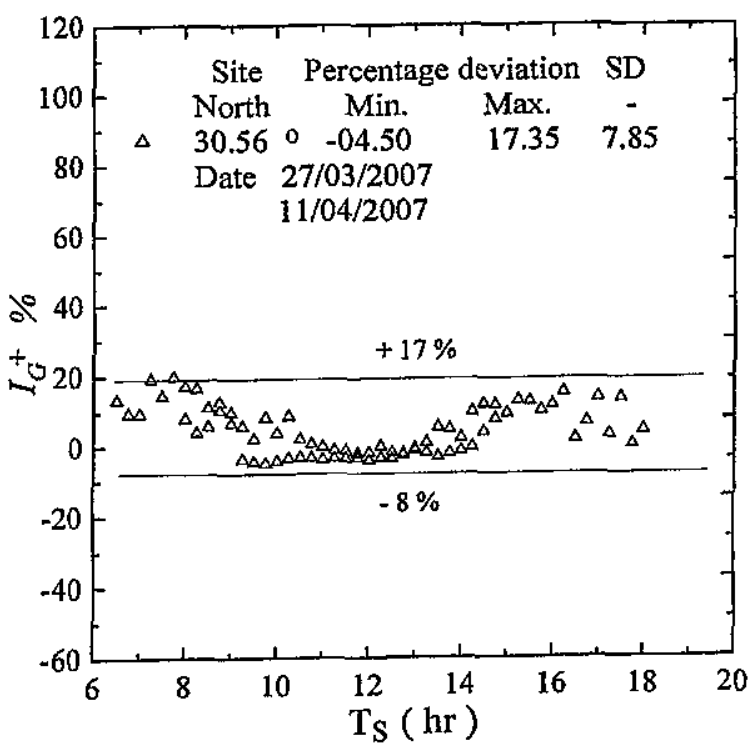

Fig. 4 Percentage deviation of global solar radiation

The prepared computer program may be considered as an effective tool to study the effect of surface azimuth and tilt angle on the solar radiation incident on a tilted surface. The effect of tilt angle was investigated from horizontal of $\Sigma=0^{\circ}$ to vertical of $\Sigma$ $=90^{\circ}$, and surface azimuth from east to west in clockwise with step of $15^{\circ}$ as shown in Fig.1. The optimum tilt angle was found to be $10^{\circ} \sim 20^{\circ}$ facing south where the total solar incident on the tilted surface was maximum at noon and at a tilt angle of $\Sigma$ $=20^{\circ}$ as shown in Fig. 5. Therefore, the tilted angle of the glazing surface of the solar distiller used in this study was limited to $20^{\circ}$.

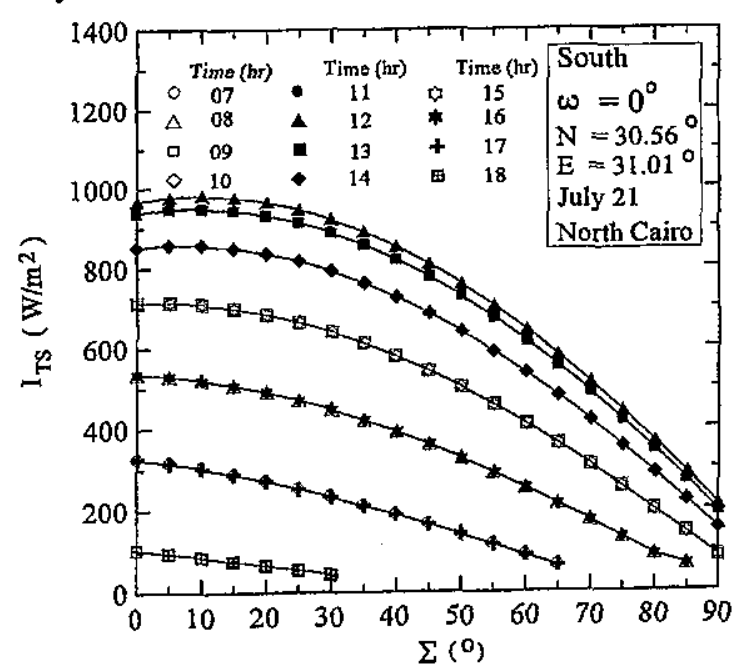

Fig. 5 Effect of surface tilted angle on incident solar radiation to south 


\section{EXPERIMENTAL APPARATUS}

The experimental apparatus was constructed in two models as shown in Figs. 6 and 7. The first model was made from wood basin of $1 \times 1 \mathrm{~m}$ with $15 \mathrm{~cm}$ height and $1.2 \mathrm{~cm}$ wood thickness. The inside faces of wood basin were covered with cement layer of about $1.5 \mathrm{~cm}$ and divided into small channels of $4 \mathrm{~cm}$ deep and $8 \mathrm{~cm}$ apart by ceramic slabs of $5 \mathrm{~mm}$ thickness. The channels were formed to decrease the water deep in the basin and the thermal capacity of the distiller, also to increase the surface area of heat and mass transfer. The auxiliary condenser was made of galvanized steel of $0.25 \mathrm{~mm}$ thickness as a rectangular shape of $30 \times 30 \times 90 \mathrm{~cm}$ to increase the heat transfer area to accelerate the condensation of water vapor.

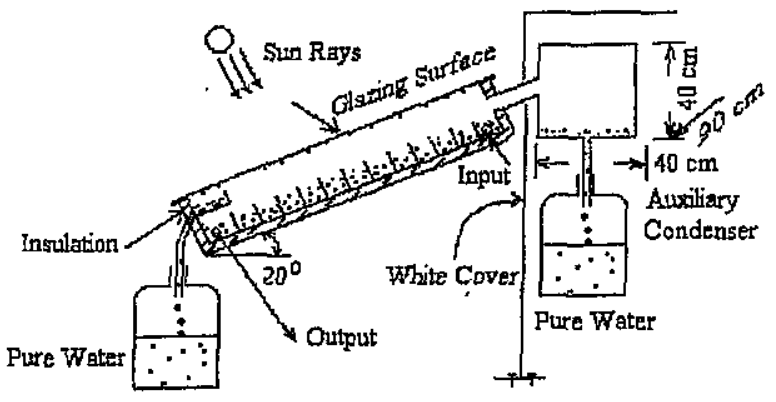

Fig. 6 Layout of cement model with auxiliary condenser solar distiller

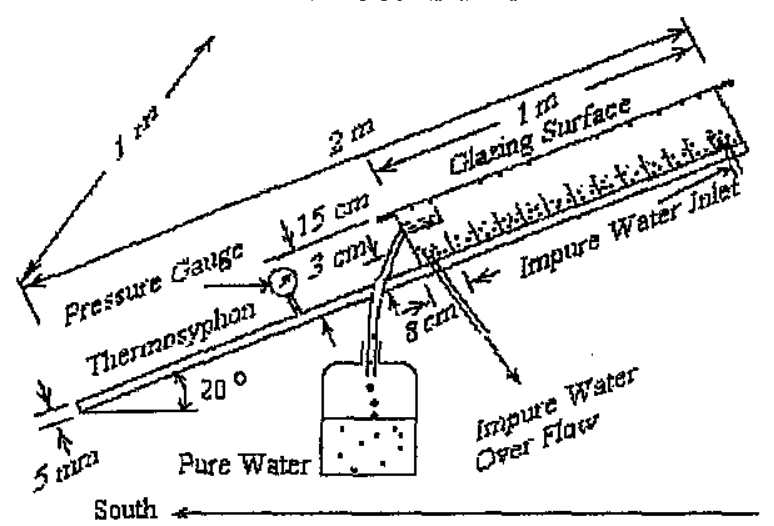

Fig. 7 Layout of aluminum model with thermosyphon solar distiller

The second model was made from aluminum sheet of $1 \mathrm{~mm}$ thickness and consists of plate thermosyphon and glazing solar distiller. The plate thermosyphon was constructed from two plates of aluminum $1 \times 2 \mathrm{~m}$ and the space between two plates was kept $2 \sim 3 \mathrm{~mm}$ by making small webs on the upper plate. The four edges of the two plates were welded together and were examined for damage before charging with Acetone. The dimension of glazing solar distiller was $1 \times 1 \mathrm{~m}$ with $15 \mathrm{~cm}$ height and fixed on the upper half of the plate thermosyphon. Parallel channels of $4 \times 8$ $\mathrm{cm}$ were formed in amphitheater shape to keep the water on the tilted surface and to decrease the thermal capacity of the distiller. Suitable ways for distributing the impure water and collecting the pure water were arranged. The transparent surface was white glass of $1 \times 1 \mathrm{~m}$ and $3 \mathrm{~mm}$ thickness and sealed to prevent the escape of water vapor. The two models were inclined $20^{\circ}$ to horizontal and all inside surfaces and channels were painted with heavy black color to absorb solar radiation. The two models were mounted on a woody frame and the base and all sides were thermally insulated.

The solar radiation incident on the tilted surface was measured by EPPLEY Radiometer which fixed at the same level and tilt angle of glazing surface. The yields or productivity of fresh water was measured by scaled flask over $l \mathrm{hr}$. The plate thermosyphon was evacuated from air and charged with one liter of acetone which equal three quarter of evaporator volume. The acetone as a working fluid was used because its boiling temperature is $57{ }^{\circ} \mathrm{C}$ at atmospheric pressure and it is convenient to this application. The photos of the two models and solar Radiometer were indicated in Fig. 8.
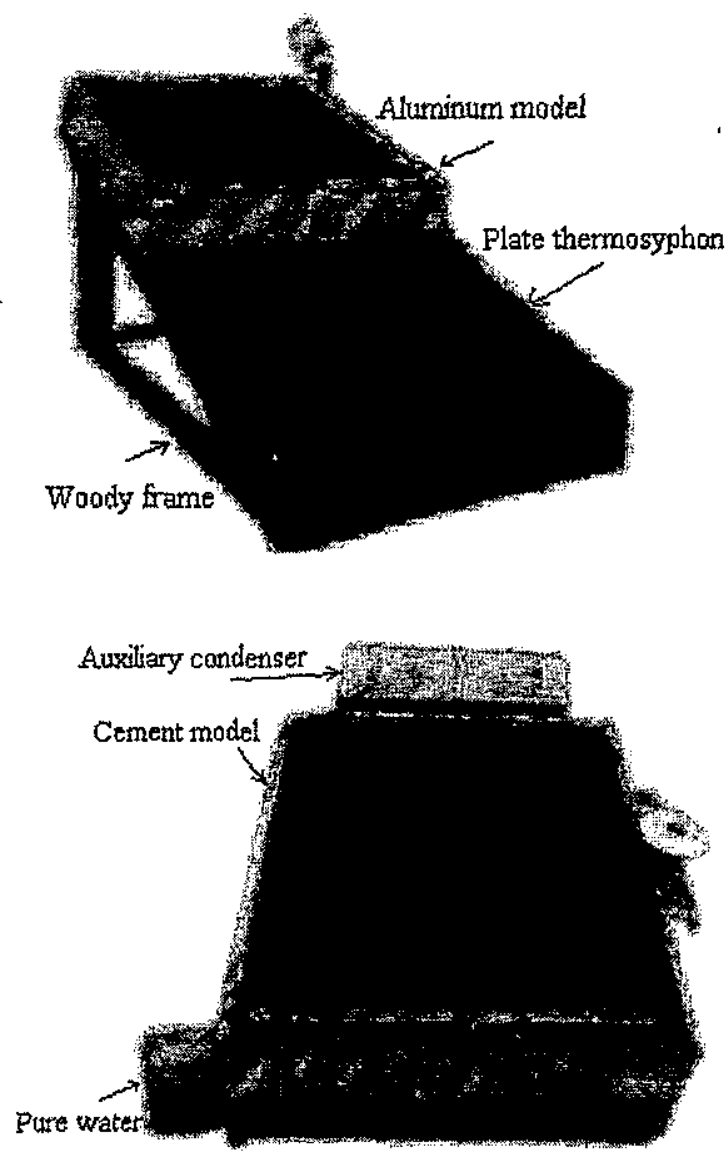

Fig. 8 Photos of cement and aluminum models with EPPLEY Radiometer 


\section{THERMAL ANALYSIS OF SOLAR DISTILLER}

The solar. radiation hits the glazing surface of solar distiller and unglazed surface of plate heat pipe. The solar radiation is transmitted through the glazing surface, water and absorbed by the black surfaces of distiller. The black surfaces re-radiate long wave radiation that is directly absorbed by the water. The upper black surface of plate heat pipe absorbed solar radiation and a part of heat is transferring to surrounding by convection and radiation, and other part is transferring through the plate heat pipe. The liquid refrigerant absorbs heat and evaporates going up to the upper half of plate heat pipe. The vapor refrigerant condenses at inner surface and condensation heat is transferred by conduction and convection to the water. The condensed refrigerant is going down under the gravity to the lower part of plate heat pipe and then repeating the cycle. The water inside the passages of solar distiller heats and evaporates. The water vapor, which consists of moisture and dry air, is freely moving up to the condensing surfaces. The temperature difference between water surface and condensing surfaces is causing the buoyancy force due to variation of vapor partial pressure.

\subsection{Transmitted Radiation and Water Heat Gain}

For short time interval, quasi steady state condition could be considered to make heat balance. The heat gain of water in the distiller is the sum of transmitted solar radiation through glazing surface and the heat transferred through plate heat pipe. The radiation transmitted through a glazing surface is dependent on the incident angle, $\theta$. Because the base of solar distiller and sides well thermally insulated, the heat losses can be neglected, so the heat gain of water can be estimated as:

$$
H_{w}=A_{g l} \alpha_{w} \tau_{g l} I_{T S}+A_{P}\left(\alpha_{P} I_{T S}-q_{P_{a}}\right)
$$

Where, $q_{P a}$ is the sum of heat loss from the unglazed surface of plate heat pipe to surrounding air by convection and radiation to sky due to the following equations [16-19].

$$
\begin{aligned}
q_{p a} & =q_{p c}+q_{p r} \\
& =h_{p c}\left(T_{p}-T_{a}\right)+F_{p-s} \sigma\left[T_{p}^{4}-T_{s k y}^{4}\right]
\end{aligned}
$$

Where, $T_{s k y}=T_{a}-10$

\subsection{Water Heat Balance and Distiller Productivity}

The heat gained by water can be expressed as [13, 22],

$H_{w}=A_{w}\left(q_{c w}+q_{r w}\right)+Q_{e w}+C_{s} \frac{d T_{w}}{d t}+F C_{p w}\left(T_{w}-T_{a}\right)$

Where,

$$
\begin{aligned}
& q_{c, v}=0.883\left[\left(T_{w}-T_{g l}\right)+\frac{\left(P_{w}-P_{w g}\right)\left(T_{w}+273\right)}{\left(2.69 P_{a}-P_{w}\right)}\right]^{\frac{1}{3}}\left(T_{w}-T_{g i}\right) \\
& q_{r w}=F_{w-g} \sigma\left(T_{w}^{4}-T_{g i}^{4}\right)
\end{aligned}
$$

The instantaneous productivity can be obtained as,

$$
D_{t}=Q_{e w} / L_{w g i}
$$

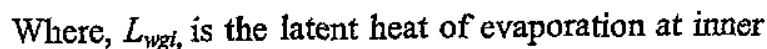
glazing surface temperature. The heat of evaporation, $q_{e w}$ can be approximately calculated as $[21]$,

$$
q_{\text {ew }}=6.1 \times 10^{-9}\left[\left(T_{w}-T_{g l}\right)+\frac{\left(P_{w}-P_{w g}\right)\left(T_{w}+273\right)}{\left(2.69 P_{a}-P_{w}\right)}\right]^{\frac{1}{3}}\left(P_{w}-P_{g^{\prime}}\right) \times L_{w w}
$$

Where, $L_{w w}$, is the latent heat of evaporation at water temperature in $\mathrm{kg}^{-1}$ and $P_{a}$ is the atmospheric pressure. $P_{w}$ and $P_{w g i}$ are the saturation vapor pressure at water temperature and inner glazing surface temperature in $\mathrm{Nm}^{-2}$ respectively.

\subsection{Glazing surface heat balance}

The heat transfer from glazing surface area to the distiller system is the sum of convection and radiation.This heat is equivalent to the water heat gain in distiller and the absorbed heat in glazing surface.

$$
A_{t} q_{g a}=H_{w}+A_{g l} \alpha_{g l} I_{T S}
$$

Where,

$$
\begin{aligned}
& q_{g a}=q_{g c}+q_{g r} \\
& q_{g c}=h_{g c}\left(T_{g o}-T_{a}\right) \\
& q_{g r}=F_{g-s} \sigma\left(T_{g o}^{4}-T_{s k y}^{4}\right)
\end{aligned}
$$

The heat transfer area, $A_{t}$, in Eq. (20) is the required area for heat dissipation to environment from distiller to maximize the productivity. The computer program was modified with the assumed clear sky solar radiation model to predict the distiller instantaneous productivity for different wind speed. Appendix A shows some important physical properties and parameters that used to perform the thermal analysis and calculation.

\section{THEORETICAL DISSIPATING HEAT TRANSFER AREA AND MAXIMUM PRODUCTIVITY}

The solar distiller thermal analysis in terms of heat transmitted to distiller or water heat gain, wind speed and temperature difference between glazing surface and surrounding air were illustrated in Fig. 9. The calculations were made for glazing surface area of 1 $\mathrm{m}^{2}$, surrounding air temperature form $20 \sim 40{ }^{\circ} \mathrm{C}$ and 
wind speed from $0 \sim 4 \mathrm{~m} / \mathrm{s}$. The results showed that when the surrounding air temperature increases from $20 \sim 40{ }^{\circ} \mathrm{C}$, that simulates the air temperature change through the daytime, the deviation was ranging of 3 $11 \%$. Also, the heat transfer area is dependent on the temperature difference between basin water and inner glazing surface and it decreases with increasing the temperature difference between water and glazing surface. Obviously, a systematic decrease of heat transfer area with increasing of wind speed and temperature difference between glazing surface and surrounding air were illustrated in Fig. 9. The dashed line in the figure at heat transfer area of $1 \mathrm{~m}^{2}$ is a distinguish badge for using auxiliary surface or not.

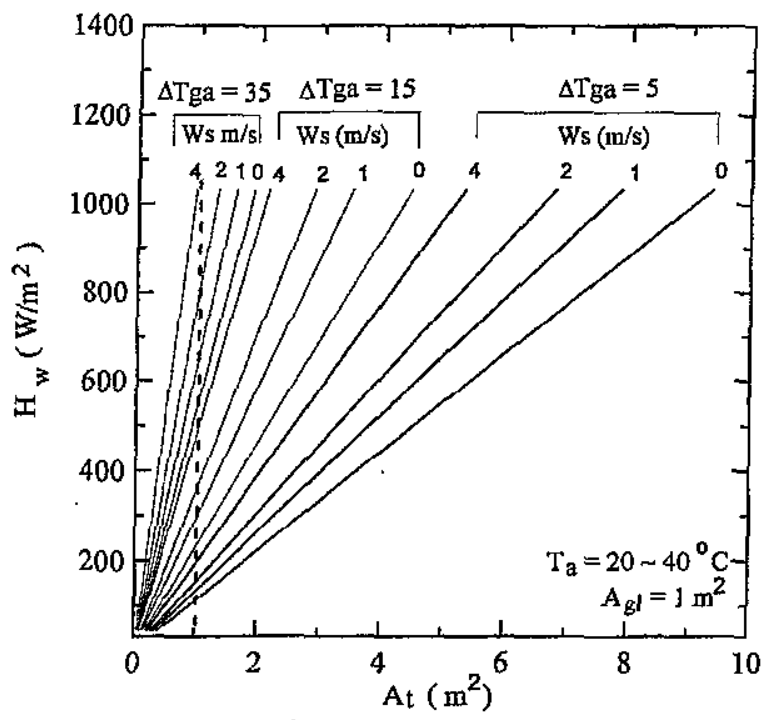

Fig. 9 Heat transfer area for dissipating heat to surrounding air

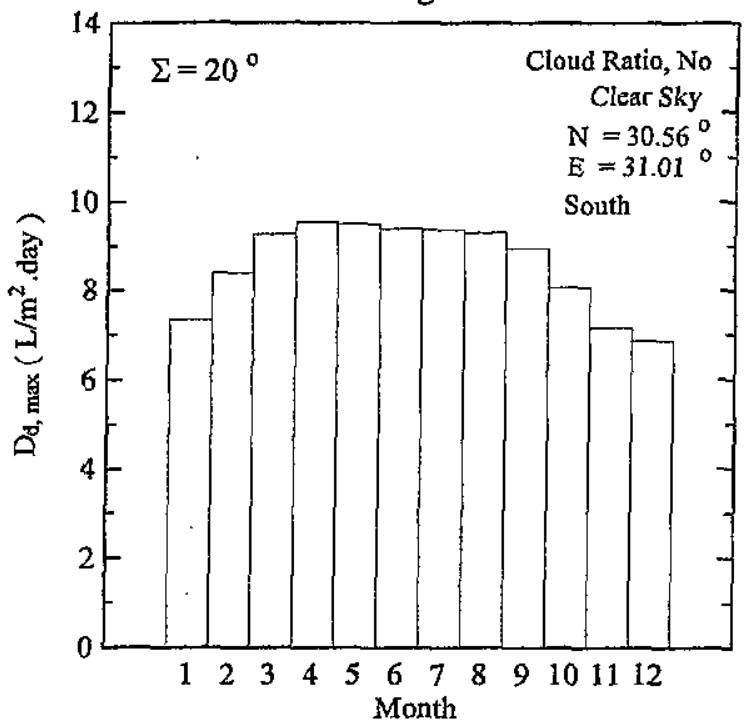

Fig. 10 Theoretical maximum productivity per day at 21 of each month

It can be seen that, at right side of dashed line, the glazing surface area is not sufficient for dissipating heat that transmitted to the distiller and auxiliary surface should be required. But at the dash line and its left side, the glazing surface is sufficient for dissipating heat and getting maximum productivity. Figure 10 shows the maximum daily productivity for glazing surface of $1 \mathrm{~m}^{2}$, and the $21^{\text {th }}$ day of each month was used as a reference. The maximum daily productivity was calculated with neglecting the radiation and convection from the water surface in the basin and also neglecting the losses from the basin sides and base.

\section{RESULTS AND DISCUSSION}

The experimental program was conducted using two models. The first model is cement absorber distiller without and with separated condenser which orientated to south. Hourly and daily productivity was obtained as shown in Fig. 11 and 12. It can be seen that the productivity increased gradually to noon and reaching maximum at about 2 hour afternoon. The experiments were repeated 2 or 4 days respectively to examine the data accuracy, and the measured values were shown in Table 1 . The daily productivity of cement absorber model was 2.08 $\mathrm{L} /\left(\mathrm{m}^{2}\right.$.day) without condenser and $2.388 \mathrm{~L} /\left(\mathrm{m}^{2}\right.$.day) with separated condenser indicating a percentage increase of about $18 \%$. The surface area of condenser used was $0.95 \mathrm{~m}^{2}$. As the measured wind velocity was less than $1 \mathrm{~m} / \mathrm{s}$ and $\Delta T_{g a}=15 K$, Fig. 9, the surface area of condenser should be in this case 3 times the glazing surface area to increase the daily productivity up to $90 \%$. It is very important to say that the cement absorber model has been used in this program because it is very cheep and easy to construct without any previous experience. Also, it is easy to build it using local materials as bricks, cement and glass beside wells, rivers, lakes and sea beach to serve the people in arid and remote areas.

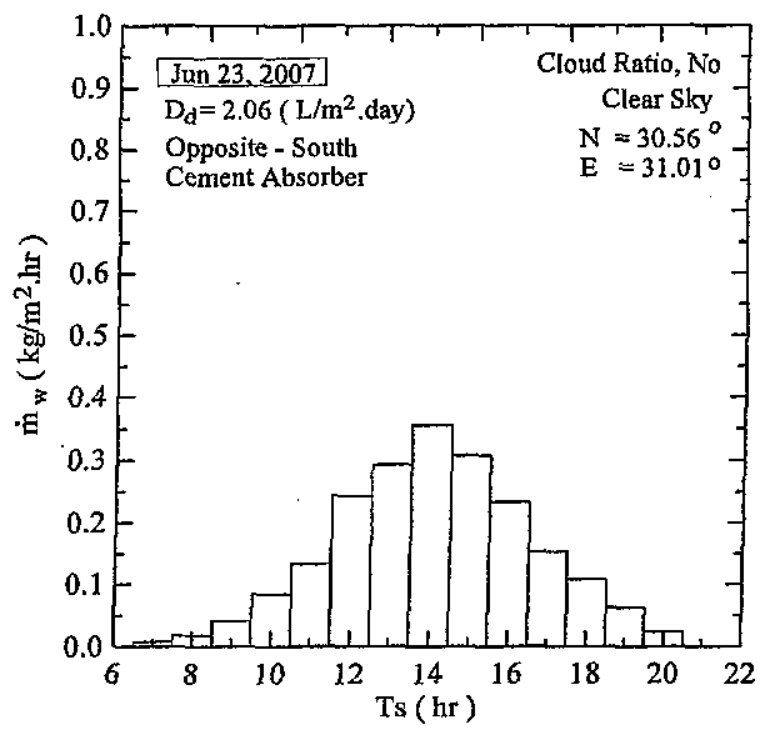

Fig. 11 Hourly productivity of cement model without condenser 


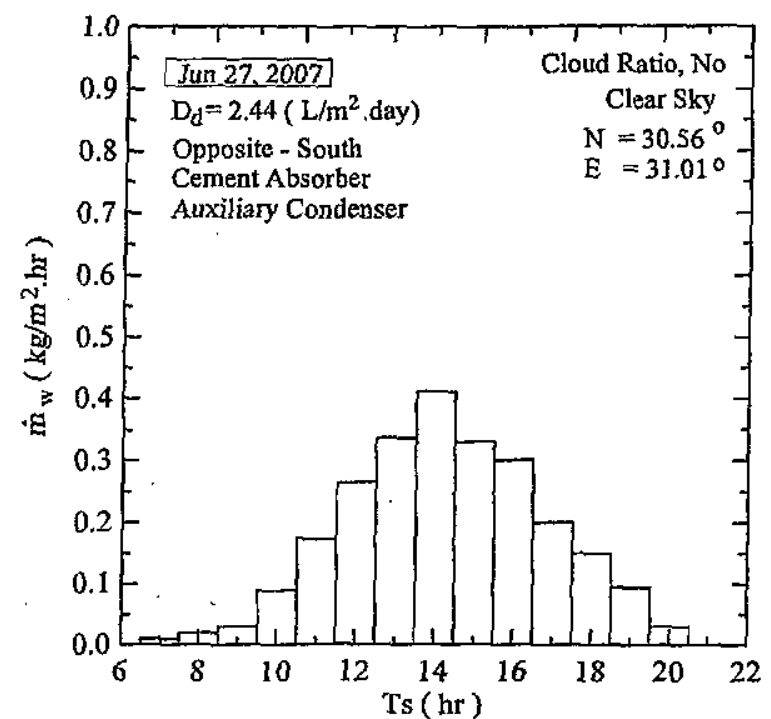

Fig. 12 Hourly productivity of cement model with condenser

The second model was aluminum absorber distiller and the experiments were conducted without thermosyphon which orientated to south. Thereafter, the distiller was rotated every $30 \mathrm{~min}$ facing the sun until its shadow underneath itself. In these experiments, the thermosyphon section did not charged with acetone and covered with thermal insulation to prevent the solar energy to strike this section. Hourly and daily productivity of aluminum absorber without thermosyphon was illustrated in Fig. 13 and 14. The daily productivity was 2.96 $\mathrm{L} /\left(\mathrm{m}^{2}\right.$.day) when orientated to south and 4.39 $\mathrm{L} /\left(\mathrm{m}^{2}\right.$.day $)$ when rotated opposite sun with percentage increase of about $48.6 \%$. The daily productivity of aluminum absorber orientated to south is higher than that of the cement absorber by about $43.69 \%$, Table 2. Because the aluminum absorber is making the temperature of black surfaces and basin water is homogenous then it accelerates the water evaporation.

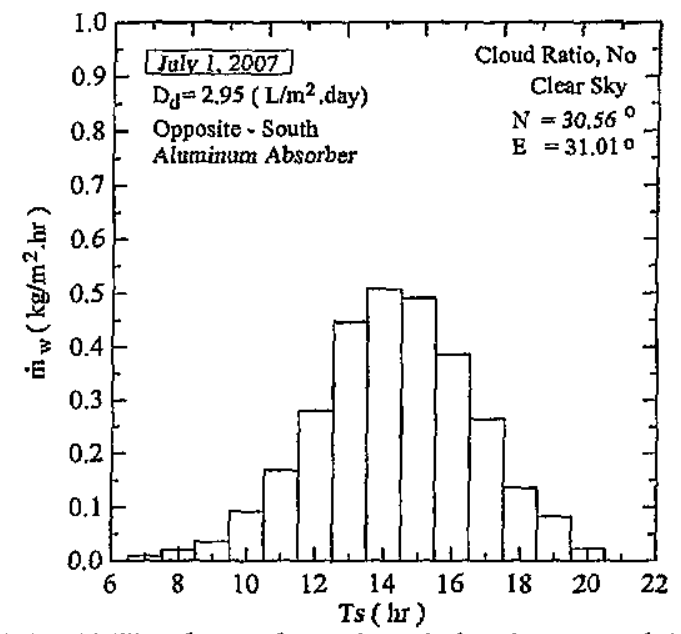

Fig. 13 Hourly productivity of aluminum model oriented to south

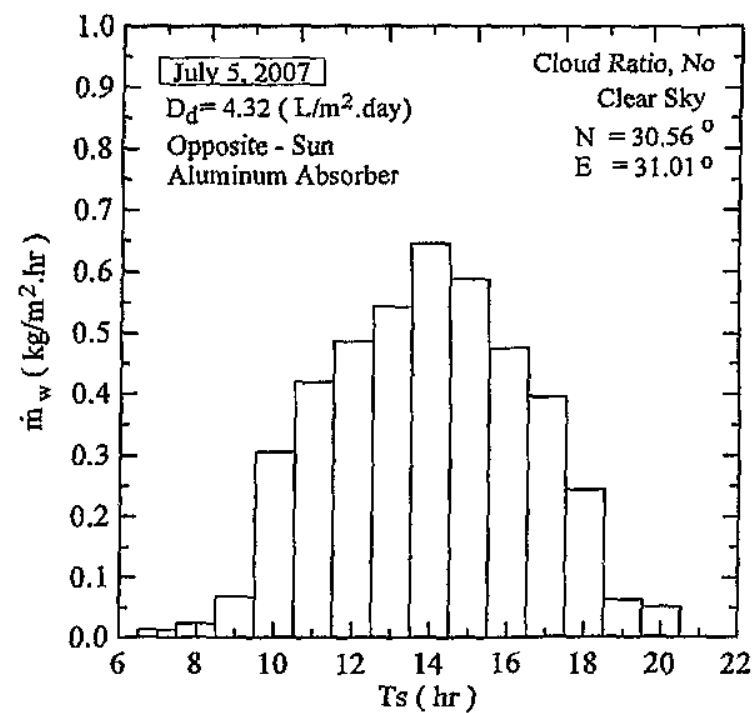

Fig. 14 Hourly productivity of aluminum model oriented to sun

When the plate thermosyphon was evacuated and charged with acetone, the measured daily productivity was $3.49 \mathrm{~L} /\left(\mathrm{m}^{2}\right.$.day) with orientation to south as shown in Fig. 15. In case of distiller with thermosyphon, the daily productivity was increased by about $18 \%$ than that without thermosyphon. If the thermosyphon distiller orientated facing the sun and its position changed every $30 \mathrm{~min}$ so that its shadow underneath itself, the daily productivity may increase up to $5.2 \mathrm{~L} /\left(\mathrm{m}^{2}\right.$.day).

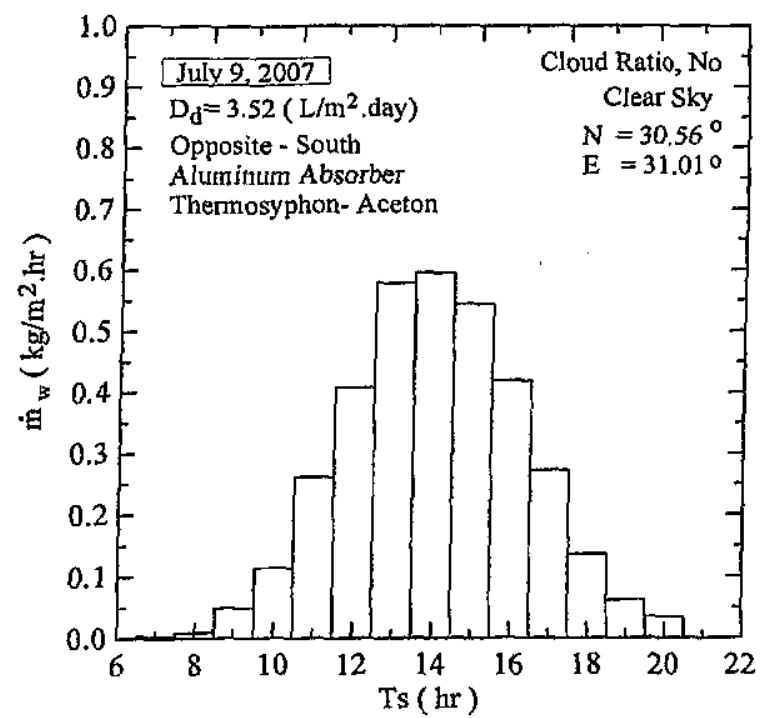

Fig. 15 Hourly productivity of aluminum model with thermosyphon

The distiller overall efficiency is depending on incident solar energy. It may be defined as the ratio between solar energy utilized for water evaporation and the solar radiation incident on glazing surface,

$\eta=\frac{\dot{m}_{w} \times L T}{H_{s}}$ 
The overall efficiency of the previous cases was indicated in Figs. 16-18. Although the solar energy increases until noon and then decreases afternoon, the distiller efficiency increases along the day. This refers back to the thermal capacity of the distiller and energy stored in black surfaces and basin water. It is found that the efficiency of cement absorber with condenser is higher by about $5 \%$ as shown in Fig. 16. While for aluminum absorber, the efficiency is higher than cement absorber by about $15 \%$ as shown in Fig. 17. For aluminum absorber, the efficiency of plate thermosyphon is higher by about $8 \%$ as illustrated in Fig. 18. But, when the aluminum absorber is rotating opposite the sun, the efficiency was increased by about $18 \%$. From these results, it may be seen that, the productivity was increased by about $18 \%$ and the overall efficiency by about $5 \sim 8$ $\%$, in case of using a cement absorber model with condenser or an aluminum absorber model with thermosyphon.

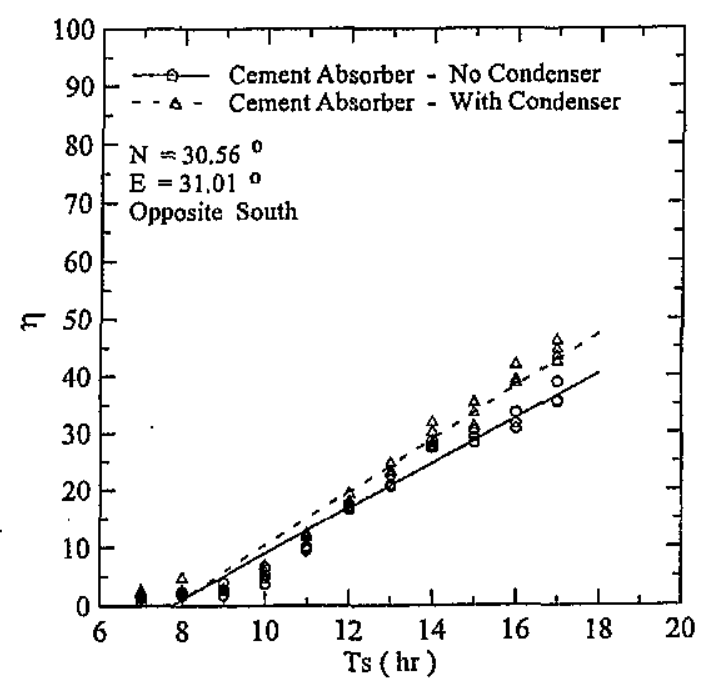

Fig. 16 Cement absorber distiller efficiency with and without condenser

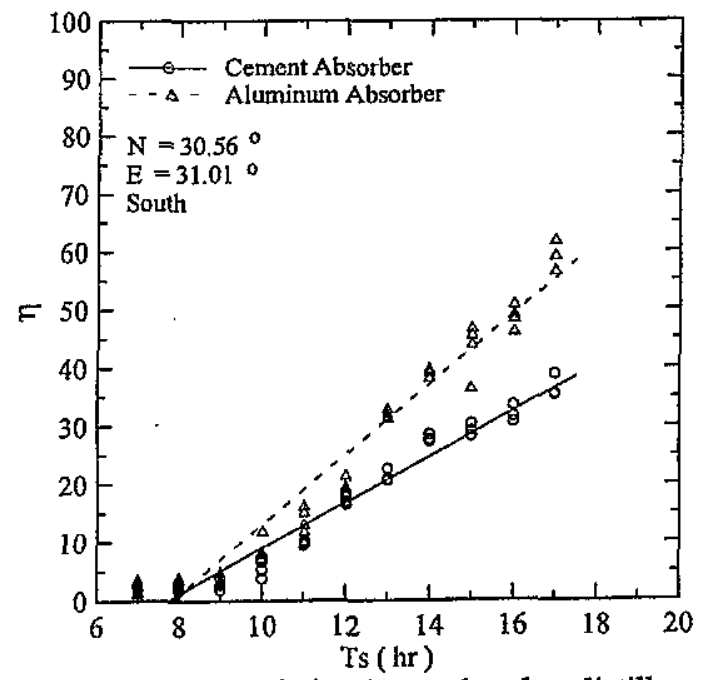

Fig. 17 Cement and aluminum absorber distiller efficiency.

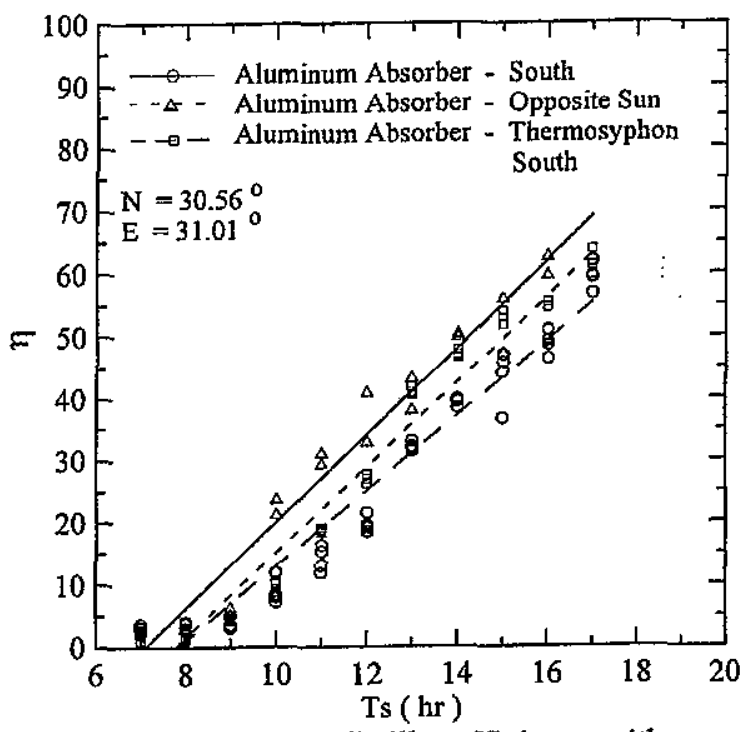

Fig. 18 Aluminum distiller efficiency with thermosyphon.

\section{CONCLUSIONS}

An experimental study was performed to investigate the productivity and efficiency of solar water distiller using cement and aluminum absorber. Two modifications were used to enhance the productivity of the distiller. For cement absorber, auxiliary condenser was used to purge the water vapor to increase the productivity. For aluminum absorber, plate thermosyphon charged with acetone was used to enhance the heat transfer underneath the water in the basin to increase the evaporation and productivity. The results are summarized as the followings:

1. The optimum tilted angle was calculated and it was found between $10 \sim 20^{\circ}$ at latitude angle of $30^{\circ}$.

2. The average daily productivity of cement absorber distiller orientated to south may reach 2.08 $\mathrm{L} /\left(\mathrm{m}^{2}\right.$.day) with overall efficiency of $38 \%$. The productivity was increased to $2.39 \mathrm{~L} /\left(\mathrm{m}^{2}\right.$.day) with overall efficiency of $45 \%$ when using auxiliary condenser. This leads to a percentage increase of about $18.7 \%$.

3. For aluminum absorber orientated to south, the average daily productivity was reached 2.96 $\mathrm{L} /\left(\mathrm{m}^{2}\right.$.day) with overall efficiency of $50 \%$. But when plate thermosyphon was applied the productivity attained to $3.49 \mathrm{~L} /\left(\mathrm{m}^{2}\right.$.day) with overall efficiency up to $65 \%$. This leads to a percentage increase of about $18 \%$.

4. In case of aluminum absorber positioned with respect to the direction of the sun, the average daily productivity was attained to $4.39 \mathrm{~L} /\left(\mathrm{m}^{2}\right.$.day) with overall efficiency of $70 \%$. 
Table 1 Hourly and daily productivity of cement absorber model.

\begin{tabular}{|c|c|c|c|c|}
\hline $\begin{array}{l}\text { Cement } \\
\text { absorber }\end{array}$ & $\begin{array}{l}\text { Date } \\
2007\end{array}$ & $\begin{array}{c}\text { Daily } \\
\text { productivity } \\
\left.\mathrm{L} / \mathrm{m}^{2} \text {.day }\right)\end{array}$ & $\begin{array}{c}\text { Average } \\
\text { productivity } \\
\mathrm{L} /\left(\mathrm{m}^{2} \text {.day }\right) \\
\end{array}$ & $\begin{array}{c}\begin{array}{c}\text { Percentage } \\
\text { increase }\end{array} \\
\end{array}$ \\
\hline Opposite & $\operatorname{Jun} 23$ & 2.06 & \multirow{3}{*}{2.077} & \multirow[b]{3}{*}{-} \\
\hline south & $\operatorname{Jun} 24$ & 2.10 & & \\
\hline $\begin{array}{c}\text { No } \\
\text { condenser }\end{array}$ & Jun 25 & 2.07 & & \\
\hline \multirow{4}{*}{$\begin{array}{l}\text { Opposite } \\
\text { south } \\
\text { With } \\
\text { condenser }\end{array}$} & Jun 27 & 2.44 & \multirow{4}{*}{2.388} & \multirow{4}{*}{$18.7 \%$} \\
\hline & Jun 28 & 2.42 & & \\
\hline & $\operatorname{Jun} 30$ & 2.34 & & \\
\hline & July 01 & 2.35 & & \\
\hline
\end{tabular}

Table 2 Hourly and daily productivity of aluminum absorber model and thermosyphon.

\begin{tabular}{|c|c|c|c|c|}
\hline $\begin{array}{l}\text { Aluminum } \\
\text { absorber }\end{array}$ & $\begin{array}{l}\text { Date } \\
2007\end{array}$ & $\begin{array}{c}\text { Daily } \\
\text { productivity } \\
\mathrm{L} /\left(\mathrm{m}^{2} \text {.day }\right)\end{array}$ & $\begin{array}{c}\text { Average } \\
\text { productivity } \\
\mathrm{L} /\left(\mathrm{m}^{2} \text {.day }\right)\end{array}$ & $\begin{array}{l}\text { Percentage } \\
\text { increase }\end{array}$ \\
\hline \multirow{4}{*}{$\begin{array}{l}\text { Opposite } \\
\text { south }\end{array}$} & $\operatorname{Jun} 30$ & 2.97 & \multirow{4}{*}{2.955} & \multirow{4}{*}{-} \\
\hline & July 01 & 2.95 & & \\
\hline & July 02 & 2.98 & & \\
\hline & July 03 & 2.92 & & \\
\hline \multirow[b]{2}{*}{ Opposite sun } & July 04 & 4.46 & \multirow{2}{*}{4.39} & \multirow{2}{*}{$48.6 \%$} \\
\hline & July 05 & 4.32 & & \\
\hline \multirow{3}{*}{$\begin{array}{l}\text { Opposite } \\
\text { south } \\
\text { with }\end{array}$} & July 07 & 3.46 & \multirow{3}{*}{3.487} & \multirow{3}{*}{$18 \%$} \\
\hline & July 08 & 3.48 & & \\
\hline & July 09 & 3.52 & & \\
\hline
\end{tabular}

\section{NOMENCLATURE}

\begin{tabular}{|c|c|c|}
\hline$A_{P}$ & $\begin{array}{l}\text { Solar radiation intensity outside } \\
\text { atmosphere } \\
\text { Unglazed area of plate heat pipe to air }\end{array}$ & $W m^{-2}$ \\
\hline$A_{g l}$ & Glazing surface area & $m^{2}$ \\
\hline$A_{w}$ & Water surface area & $m^{2}$ \\
\hline$A_{t}$ & Heat trainsfer area & $m^{2}$ \\
\hline$B$ & $\begin{array}{l}\text { Weakness atmospheric factor of } \\
\text { solar radiation }\end{array}$ & - \\
\hline$C$ & Diffuse radiation factor & - \\
\hline$C_{s}$ & Distiller thermal capacity & $J K^{-1}$ \\
\hline $\begin{array}{l}C_{p w} \\
D_{d}\end{array}$ & $\begin{array}{l}\text { Water specific heat } \\
\text { Daily ditillate }\end{array}$ & $\begin{array}{l}J \mathrm{~kg}^{-1} K^{-1} \\
\mathrm{Lm}^{-2} \mathrm{day}\end{array}$ \\
\hline & distiller rate or productivity & $k_{g s}-1$ \\
\hline$F$ & Feed water flow rate & $\mathrm{Kgs}^{-1}$ \\
\hline$F_{S S}$ & $\begin{array}{l}\text { Angle factor between tilted } \\
\text { surface and sky }\end{array}$ & - \\
\hline$F_{S g}$ & $\begin{array}{l}\text { Angle factor between tilted } \\
\text { surface and ground surface }\end{array}$ & - \\
\hline$H$ & Solar hour angle & $=-3$ \\
\hline$H_{s}$ & $\begin{array}{l}\text { Measured solar radiation incident } \\
\text { on glazing surface }\end{array}$ & $W m^{-2}$ \\
\hline $\begin{array}{l}H_{W} \\
h\end{array}$ & $\begin{array}{l}\text { Water heat gain } \\
\text { Heat transfer coefficient }\end{array}$ & $W$ \\
\hline $\begin{array}{l}n \\
h_{c w}\end{array}$ & $\begin{array}{l}\text { Heat transfer coefficient } \\
\text { Convective heat transfer } \\
\text { coefficient from water to glass }\end{array}$ & $\begin{array}{l}W m^{-2} K \\
W m^{-2} K\end{array}$ \\
\hline$h_{e w}$ & $\begin{array}{l}\text { Evaporative heat transfer } \\
\text { coefficient }\end{array}$ & $W m^{-2} K$ \\
\hline$I_{G}$ & $\begin{array}{l}\text { Global solar radiation on } \\
\text { horizontal surface }\end{array}$ & \\
\hline
\end{tabular}

$I_{N D}$ Normal direct solar radiation $\mathrm{Wm}^{-2}$ intensity

$I_{N S}$ Normal component of solar $\mathrm{Wm}^{-2}$ radiation on the tilted surface

$I_{T S}$ Total solar radiation incident on $\mathrm{Wm}^{-2}$

The tilted surface

$L \quad$ Latitude angle of location

$L_{g} \quad$ Longitude angle of location

LT Latent heat of evaporation $\quad \mathrm{kg}^{-1}$

$\dot{m}_{w}$ Hourly productivity $\mathrm{kgm}^{-2} \mathrm{hr}^{-I}$

$n \quad$ Day number from first of January

$P_{a} \quad$ Atmospheric pressure $\mathrm{Nm}^{-2}$

$P_{w} \quad$ Saturated vapor partial pressure at $\mathrm{Nm}^{-2}$ water temperature

$P_{\text {wg }} \quad$ Saturated vapor partial pressure at $\mathrm{Nm}^{-2}$

$P_{\mathrm{wg}}$ inner glass temperature

$S \quad$ Solar beam angle to south

$T$ Temperature $K$

$T_{S} \quad$ Solar time $\quad h r$

$T_{C} \quad$ Local time of selected location $\quad h r$

$T_{\mathrm{ZN}}$ Time zone longitude angle of 0 selected location

$W \quad$ Solar beam angle to west

$W_{S} \quad$ Wind speed $\mathrm{ms}^{-1}$

$Z \quad$ Solar beam angle with vertical $\circ$

$\Sigma \quad$ Surface tilted angle

$\alpha \quad$ Absorbitivity

$\beta \quad$ Solar altitude angle

$\varepsilon \quad$ Emissivity

$\delta$ Solar declination angle

$\phi \quad$ Solar azimuth angle

$\gamma \quad$ Solar plan azimuth angle

$\eta \quad$ Distiller efficiency

$\theta \quad$ Solar incident angle

$\rho_{8}$ Reflection factor form earth 0

$\rho_{8} \quad$ surface

$\sigma \quad$ Stefan-Boltzmann constant $\quad \mathrm{Wm}^{-2} \mathrm{~K}^{4}$

$\tau$ Transmitivity

$\psi \quad$ Surface azimuth angle

\section{Subscripts}

$\begin{array}{ll}a & \text { environment } \\ d s & \text { diffuse } \\ c w & \text { convective water } \\ e w & \text { evaporation water } \\ g l & \text { glass } \\ g c & \text { glass convection to air } \\ g i & \text { inner surface of glass } \\ g o & \text { outer surface of glass } \\ g r & \text { radiation from out surface glass } \\ o & \text { environment } \\ p & \text { plate } \\ p a & \text { plate to air } \\ p c & \text { plate convection to air } \\ p r & \text { plate radiation to sky }\end{array}$


$R g$ reflection from earth surface

$s k \quad$ sky temperature

$y$

w water

cw convection from water surface

ew evaporation from water surface

$r w$ radiation from water surface

\section{REFERENCES}

[1] Kalogirou S., Survey of solar desalination system and system selection, Energy, Vol. 22, No. 1 (1997) 69.81.

[2] Abu-Jabal M., Kamiya I., Narasaki Y., Proving test for a solar-powered desalination system in Gaza-Palestine, Desalination, Vo1. 1137 (2001) 1-6.

[3] John Ward, A plastic solar water purifier with high output, Solar Energy, Vol. 75 (2003) 433437.

[4] Ali A. Badran et al., A Solar Distiller Augmented with a flat-plate collector, Desalination, Vol. 172 (2005) 227-234.

[5] Schwarzer K. Vieira M. E., Faber C., Mueller C., Solar thermal desalination system with heat recovery, Desalination, Vol. 137 (2001) 23-29.

[6] Mailk, M. A. S., Tiwari, G. N., Kumar A., Sodha M. S., Solar didistilleration-a practical study of a wide range of distillers and their optimum design, construction and performance, Pergamon Press (1992).

[7] Shawaqfeh A. T., Farid M. M., New development in the theory of heat and mass transfer in solar distillers, Solar Energy, Vol. 55, No. 6 (1995) 527-535.

[8] Klemens Schwarzer et al., Modular solar thermal desalination system with flat plate collector, RIO 3 - World Climate \& Energy Event, 1-5 December (2003) 281-286, Rio de Janeiro, Brazil.

[9] Zaki G. M., Dali T. El, Shafie H. El, Improved performance of solar distiller, proc. First Arab Int. Solar Energy Conf., Kuwait (1983) 331335.

[10]Tanaka H., Nakataka Y., A vertical multipleeffect diffusion-type solar distiller coupled with a solar collector, Desalination, Vol. 160 (2004) 195-205.
[11]Tanaka H., Nakatake Y., Watanabe K., Parametric study on a vertical multiple-effect diffusion-type solar with a heat-pipe solar collector, Desalination, Vol. 171 (2004) 243255.

[12] Tanaka H., Nakatake Y., Tanaka M., Indoor experiments of the vertical multiple-effect diffusion-type solar distiller coupled with a heat-pipe solar collector, Desalination, Vol. 177 (2005) 291-302.

[13]El-Bahi A., Inan D., Analysis of a parallel double glass solar distiller with separate condenser, Renewable Energy Vol. 17 (1999) 509-521.

[14]El-Bahi A., Inan D., A solar distiller with minimum inclination coupled to an outside condenser, Desalination, Vol. 123 (1999) 7983.

[15]ASHRAE (1981), Handbook of fundamentals, American Society of Heating, refrigeration and Air conditioning Engineers, Atlanta, W.S.A.

[16] Fath H.E.S, El-Samanoudy M., Fahmy K., Hassabou A., Therma-economic analysis and comparison between pyramid-shaped and single-slop solar distiller configurations, Desalination, Vol. 159 (2003) 69-79.

[17] Zeinab S., Abdel-Rahim, Ashraf L., Imporoving the performance of solar desalination systems, Renewable Enegry Vol. 30 (2005) 1955-1971.

[18] Anil Kr.T., Tiwari G.N., Effect of water depth on heat and mass transfer in a passive solar distiller: in summer climatic condition, Desalination Vol. 195 (2006) 78-94.

[19]Dunkle R.V., Solar water didistilleration, the roof type distiller and multiple effect diffusion distiller, International Developments in Heat Transfer, ASME, Proc. International Heat Transfer, Part V, University of Colorado, (1961) 895.

[20] Incropera F.P., DeWitt D. P., Fundamentals of Heat and Mass Transfer, Fourth Edition, JOHN WILEY \& SONS, (1996) 684.

[21]Elsayed M.M., Taha I.S., Sabbagh J.A., Design of Solar Thermal System, Scientific Publishing Center, King Abdulaziz University, Saudi Arabia, 1st Edition (1994) 194.

[22] Duffie JA, Beckman WA, Solar Engineering of Thermal Processes, $2^{\text {nd }}$ ed. New York, Wiley Inter-science (1991). 